\title{
Indonesia's Experience: Implementing Gender Responsive Planning and Budgeting
}

\author{
Fithriyah' \\ Ministry of National Development Planning/BAPPENAS
}

\begin{abstract}
This paper is a historical review of Indonesia's experience in implementing Gender Responsive Planning and Budgeting (GRPB). National Development Planning Agency/ Bappenas has initiated the implementation of gender mainstreaming in Indonesia's national development planning policies since 1999. It was started in 1998 by developing Gender Analysis Pathway, the tool for conducting gender analysis in the development planning. The tool focuses the gender gap analysis in four aspects: access, participation, control and benefit of development, between men and women, and the special needs groups. In 2008, Bappenas initiated the GRPB Steering Committee and Technical Teams, which included Ministry of Finance in board of GRPB's Steering Committe, together with Bappenas and Ministry of Women Empowerment. The team also included Ministry of Home Affairs; Education; and Health, and formally established by Minister of National Development Planning's decree in 2009. In 2012, Bappenas developed The Gender Equity \& Equality Index and Gender Mainstreaming Institutionalization Indicators to measure the progress of Gender Equality in Development. This was followed by the Circular Letter: "National Strategy to Accelerate Gender Mainstreaming through Gender Responsive Planning and Budgeting", which was signed by four ministers. The National Strategy is developed to ensure that GRPB implementation both at national and regional level is aligned, systemized, on target and also supporting the practice of good governance, sustainable development, as well as the achievement of the Millennium Development Goals (MDGs). In 2014, GRPB had been implemented in 36 line ministries and 34 provinces
\end{abstract}

Keywords: Public Policy, Government, Gender Inequality 


\section{Pengalaman Indonesia dalam Menerapkan Perencanaan dan Penganggaran yang Responsif Gender (PPRG)}

\section{Pendahuluan: Pengarusutamaan Gender di Indonesia}

Pada tahun 1999, untuk pertama kalinya kesetaraan gender dimasukkan sebagai salah satu tujuan pembangunan dalam Ketetapan Majelis Permusyawaratan Rakyat Republik Indonesia Nomor IV/MPR/1999 tentang Garis-garis Besar Haluan Negara (GBHN) Tahun 2000-2004, yaitu mewujudkan kesetaraan gender. Kesetaraan Gender mengacu kepada kondisi kesetaraan antara laki-laki dan perempuan dalam hak, tanggung jawab, dan kesempatan. Kesetaraan tidak berarti bahwa perempuan dan laki-laki menjadi sama, tapi mengimplikasikan bahwa minat, kebutuhan, dan prioritas laki-laki dan perempuan dipertimbangkan, dengan memperhatikan keragaman grup laki-laki maupun perempuan (UN 2001).

Pada tahun 1998, Bappenas bekerja sama dengan CIDA-Kanada, dan didukung oleh Kementerian Negara Pemberdayaan Perempuan (KNPP) telah menyusun peranti analisis, yang dikenal dengan nama Gender Analysis Pathway atau GAP, sebagai peranti untuk para perencana dalam melakukan analisis dan perumusan kebijakan/ program/ kegiatan pembangunan menjadi responsif gender. Peranti GAP tersebut selanjutnya mengalami beberapa kali penyempurnaan, dan versi terakhir adalah tertanggal 22 September 2007, sebagaimana tercantum pada Gambar 1 di bawah ini (PPN/Bappenas dan KNPP 2007).

Gambar 1. Gender Analysis Pathway (GAP)

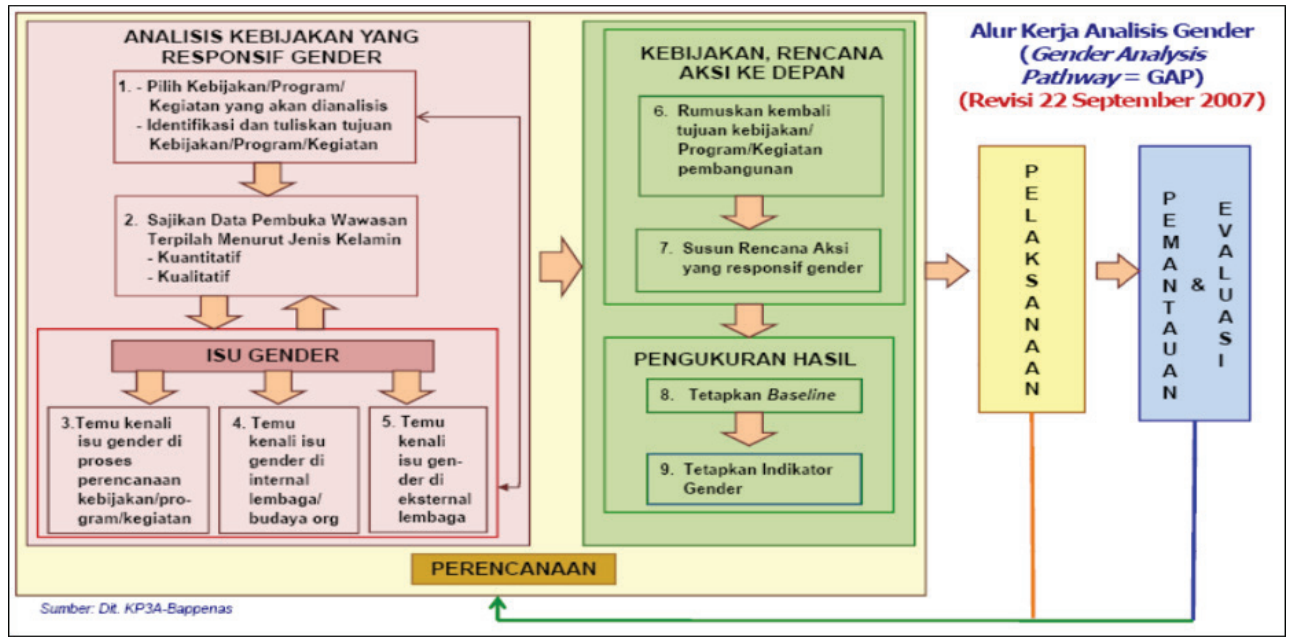

Sumber: Gender Analysis Pathway, Bappenas-KNPP, 2007

Isu gender yang dianalisis meliputi empat aspek, yaitu: 1) akses; 2) partisipasi; 3) kontrol terhadap sumber daya; dan 4) manfaat. Ada beberapa peranti lain yang dapat digunakan dalam analisis gender, seperti Harvard, Moses, Proba atau lainnya. 
Hal terpenting dalam analisis gender tersebut adalah mampu terjawabnya lima pertanyaan berikut:

1) Apakah bentuk kesenjangan gendernya?

2) Di mana dan siapa yang mengalami kesenjangan tersebut?

3) Apa penyebabnya?

4) Bagaimana kebijakan/ rencana aksi yang harus dilakukan untuk mengurangi kesenjangan gender tersebut?

5) Bagaimana cara mengukur efektivitas/ efisiensinya?

Kesetaraan gender dalam GBHN 1999-2004 kemudian dijabarkan dalam Undang-undang Nomor 25 Tahun 2000 Tentang Program Pembangunan Nasional (PROPENAS) tahun 2000-2004. Hal ini ditindaklanjuti dengan dikeluarkannya Inpres No. 9 Tahun 2000, tentang Pengarusutamaan Gender dalam Pembangunan Nasional. Inpres tersebut mengamanatkan kepada seluruh Menteri; Kepala Lembaga Pemerintah Non Departemen; Pimpinan Kesekretariatan Lembaga Tertinggi/ Tinggi Negara; Panglima Tentara Nasional Indonesia; Kepala Kepolisian Repulik Indonesia; Jaksa Agung Republik Indonesia; Gubernur; dan Bupati/Walikota, untuk melaksanakan pengarusutamaan gender guna terselenggaranya perencanaan, penyusunan, pelaksanaan, pemantauan, dan evaluasi atas kebijakan dan program pembangunan nasional yang berperspektif gender sesuai dengan bidang tugas dan fungsi, serta kewenangan masing-masing.

Kesetaraan gender diwujudkan melalui strategi Pengarusutamaan Gender (PUG). PUG diperlukan karena: 1) Masih terdapatnya kesenjangan dalam pemerataan hasil-hasil pembangunan di berbagai bidang, baik terhadap perempuan, maupun laki-laki; 2) Kesenjangan tersebut dapat dikelompokkan ke dalam empat aspek utama: akses, partisipasi dalam proses pembangunan/ pengambilan keputusan, kontrol terhadap sumber daya, maupun manfaat pembangunan; dan 3) Program kesetaraan gender dan/ atau pemberdayaan perempuan selama ini hanya meliputi sosialisasi/ advokasi untuk perempuan belaka, tidak menyentuh pada substansi inti kegiatan/ program pembangunan, dan tidak menyentuh laki-laki yang juga tertinggal di beberapa bidang pembangunan. Oleh sebab itu, perlu diterapkan strategi pengarusutamaan gender, yang meliputi setiap tahapan dalam pembangunan di berbagai bidang, untuk menghapuskan kesenjangan tersebut.

Penerapan GAP sebagai peranti analisis gender dalam perencanaan dapat dilihat hasilnya dengan 19 program pembangunan yang responsif gender pada dokumen perencanaan, yaitu GBHN (1999-2004), yang kemudian dilanjutkan pada Program Pembangunan Nasional (Propenas) 2000-2004. Program-program tersebut mencakup 5 sektor pembangunan yaitu hukum, ekonomi, politik, pendidikan, dan sosial budaya. Pada setiap Rencana Pembangunan Tahunan (Repeta) upaya PUC terus dilakukan, dan hasil nyata yang diperoleh adalah bertambahnya program yang responsif gender. Hingga Repeta 2004, jumlah program yang telah responsif gender bertambah menjadi 38 program, dengan 19 program tambahan dari 4 sektor, yaitu kesejahteraan sosial, lingkungan hidup, keluarga berencana, dan kesehatan. Selanjutnya pada periode perencanaan lima tahunan berikutnya, yaitu Rencana Pembangunan Jangka Menengah Nasional (RPJMN) 2004-2009, upaya dilanjutkan dengan menetapkan gender sebagai salah satu prinsip pengarusutamaan untuk seluruh program/ kegiatan pembangunan.

\section{Percepatan Pengarusutamaan Gender Melalui Perencanaan dan Penganggaran yang Responsif Gender (PPRG)}

Pada tahun 2007, Bappenas melakukan kajian "Analisis Gender dalam Pembangunan," yang bertujuan untuk melakukan evaluasi terhadap pelaksanaan PUG setelah tujuh tahun dikeluarkannya Inpres No. 9 tahun 2000, di 18 kementerian/ lembaga, 7 provinsi, dan 7 kabupaten/ kota terpilih. Hasil dari evaluasi tersebut 
menunjukkan bahwa strategi PUG belum dilaksanakan sepenuhnya dengan baik di sebagian besar bidang pembangunan. Oleh sebab itu, dalam rangka mempercepat pelaksanaan PUG, perspektif gender tidak hanya diintegrasikan ke dalam sistem perencanaan tetapi juga penganggaran. Inisiatif ini dimulai dengan dikeluarkannya Surat Keputusan Menteri Negara PPN/ Kepala Bappenas Nomor Kep.30/M.PPN/ HK/03/2009 tentang Tim Pengarah dan Tim Teknis Perencanaan dan Penganggaran yang Responsif Gender (PPRG). Tim ini dibentuk untuk mengoordinasikan pelaksanaan PPRG lintassektor dan lintaskementerian/ lembaga.

Upaya mempercepat pelaksanaan PUG dilakukan melalui uji coba pelaksanaan anggaran responsif gender (ARG). Untuk pertama kalinya dalam RPJMN 2010-2014, kebijakan pengarusutamaan gender diintegrasikan ke dalam sistem perencanaan dan penganggaran, yang memuat kebijakan, indikator, dan sasaran yang terpilah berdasarkan jenis kelamin dari berbagai kementerian dan lembaga, dan melibatkan seluruh pemangku kepentingan terkait dalam penyusunannya (Bappenas 2010). Periode ini merupakan saat yang tepat untuk mengintegrasikan kesetaraan dan keadilangender kedalamsistem penganggaran, karena Indonesia sedang menjalankan reformasi sistem keuangan negara melalui Unified Budgeting, Performance-based Budgeting (PBB), dan Medium Term Expenditure Framework (MTEF).

Hal ini ditindaklanjuti dengan dikeluarkannya Peraturan Menteri Keuangan Nomor 119/PMK.02/2009 tentang Petunjuk Penyusunan dan Penelaahan Rencana Kerja dan Anggaran K/L dan Penyusunan, Penelaahan, Pengesahan dan Pelaksanaan DIPA Tahun Anggaran 2010, dan dilanjutkan dengan Peraturan Menteri Keuangan Nomor 104/PMK.02/2010 tentang Petunjuk Penyusunan dan Penelaahan Rencana Kerja dan Anggaran Kementerian Negara/Lembaga Tahun Anggaran (T.A.) 2011, yang turut mempercepat pelaksanaan ARG.

Lampiran dalam peraturan ini menyatakan bahwa pada T.A. 2010, ARC diujicobakan pada 7 kementerian dan lembaga pilot, yaitu pada 3 kementerian/ lembaga sebagai penggerak PPRG (Kementerian PPN/ Badan Perencanaan Pembangunan Nasional, Kementerian Negara Pemberdayaan Perempuan, dan Departemen Keuangan) dan 4 kementerian sebagai pelaksana/ service delivery (Departemen Kesehatan, Departemen Pertanian, Departemen Pendidikan Nasional, dan Departemen Pekerjaan Umum). Setiap kementerian/lembaga pelaksana menyusun gender budget statement (GBS), yang merupakan dokumen akuntabilitas spesifik-gender yang disusun oleh K/L untuk menginformasikan bahwa suatu kegiatan sudah responsif gender, dan kemudian menyampaikannya kepada Kemkeu sebagai bagian dari dokumen RKA-KL, yang melengkapi kerangka acuan kegiatan (TOR). Pada T.A. 2011, PMK tersebut mencantumkan bahwa ARG diterapkan di berbagai bidang prioritas pembangunan, terutama yang terkait dengan bidang politik, sosial, hukum, dan ekonomi (tidak terbatas pada K/ L pilot).

Pada tahun 2011, Kemkeu menetapkan PMK Nomor 93/PMK.02/2011 tentang Petunjuk Penyusunan dan Penelaahan Rencana Kerja dan Anggaran Kementerian Negara/Lembaga. PMK ini merupakan dasar penerapan ARG untuk T.A. 2012 dan tahun selanjutnya, karena masa berlakunya yang tidak hanya satu tahun, sebagaimana PMK sebelumnya. Untuk T.A. 2012, ARC tersebut diterapkan di 28 kementerian/ lembaga dan 10 provinsi (melalui dana dekonsentrasi dari KPP\&PA, yaitu: Jatim, Jateng, DIY, Banten, Jabar, Sumut, Babel, Kepri, Kalbar, dan Lampung). Hingga tahun 2014, PPRC ini telah diterapkan di 34 provinsi dan $36 \mathrm{~K} / \mathrm{L}$.

Di samping itu, dilakukan pula penyebaran data, informasi, kebijakan, dan materi sosialisasi gender, terkait PUG (termasuk percepatannya melalui PPRG) melalui situs PPRG-Bappenas (Bappenas, PPRG 2010). Situs tersebut bebas diakses oleh siapa saja, tidak hanya bagi staf Bappenas, dan telah dijadikan rujukan pula oleh Pemda atau K/ L dalam penerapan PUG di daerah/instansinya. 


\subsection{Indeks Kesetaraan dan Keadilan Gender (IKKG) dan Indikator Kelembagaan Pengarusutamaan Gender (IKPUG)}

Pada tahun 2012, Kedeputian SDMK-Bappenas telah menyusun Kajian Awal: Indeks Kesetaraan dan Keadilan Gender (IKKG) dan Indikator Kelembagaan Pengarusutamaan Gender (IKPUG). IKKG ini merupakan penyempurnaan dari Gender Inequality Index (GII)-UNDP, dengan memasukkan aspek perlindungan terhadap berbagai tindak kekerasan, serta mengukur capaian pembangunan RPJMN terkait Kesetaraan Gender dan Pemberdayaan Perempuan dari sisi output dan outcome (Sanjoyo, et al. 2012).

Kajian tersebut mencantumkan alat ukur yang diperlukan untuk mengevaluasi keberhasilan pembangunan kesetaraan dan keadilan gender dalam RPJPN 20052025 (RI 2007) dan RPJMN 2010-2014 (Bappenas, 2010), yang mencakup dua kelompok pengukuran, yaitu:

a. Indikator Komposit (Indeks) Kesetaraan dan Keadilan Gender (IKKG) IKKG mengukur kualitas hidup perempuan dan laki-laki dalam hal akses dan perannya dalam pembangunan, serta kapasitasnya dalam mengontrol, serta sebagai penerima manfaat dari pembangunan. Indeks ini mengukur sejauh mana kesetaraan dan keadilan gender telah terwujud.

b. Indikator Kelembagaan Pengarusutamaan Gender (IKPUG) IKPUG mengukur efektivitas kelembagaan pengarusutamaan gender (PUG) sebagai strategi kebijakan yang dipakai dalam mewujudkan kesetaraan dan keadilan gender. Indeks ini mengukur sejauh mana perangkat kebijakan telah tersedia dan dipergunakan untuk mendukung proses pengarusutamaan gender ke dalam pembangunan.

Tujuan umum dari kajian ini adalah menyusun dan menghitung Indeks Kesetaraan dan Keadilan Gender (IKKG) di level nasional dan provinsi yang mencakup pengukuran atas: a) Kualitas hidup perempuan dibanding laki-laki terutama dalam aspek kesehatan, pendidikan dan ekonomi; b) Perlakuan diskriminatif yang diterima perempuan dibanding laki-laki di tempat kerja; c) Kekerasan yang dialami perempuan dibanding laki-laki di ranah publik, domestik dan negara; dan d) Merumuskan Indikator Kelembagaan Pengarusutamaan Gender (IKPUG), sebagai tolok ukur efektivitas strategi kebijakan bagi mewujudkan kesetaraan dan keadilan gender. Dalam hal ini, IKPUC menjadi tolok ukur ketersediaan komponen-komponen kelembagaan PUC yang sangat diperlukan dalam proses perencanaan, pelaksanaan, serta monitoring dan evaluasi kebijakan, program dan kegiatan pembangunan yang responsif gender. Oleh karena itu, IKPUG mencakup: 1) Ketersediaan peraturan perundangan yang responsif gender; 2) Ketersediaan lembaga-lembaga yang mendukung proses pelaksanaan PUG, termasuk data dan anggaran; 3) Ketersediaan sumber daya manusia yang mendukung proses pelaksanaan PUG; dan 4) Ketersediaan dukungan masyarakat dan dunia usaha dalam proses pelaksanaan PUG.

Adapun tujuan khusus dari penyusunan IKKG adalah:

1. Mengidentifikasi indikator-indikator terkait kesetaraan dan keadilan gender yang telah tersedia dalam survai nasional, termasuk yang terkait dengan diskriminasi dan perlindungan perempuan.

2. Mengidentifikasi indikator-indikator kesetaraan dan keadilan gender yang tersedia pada berbagai laporan dari Kementerian, Kepolisian, Lembaga Swadaya Masyarakat dan lembaga lainnya, termasuk yang terkait dengan diskriminasi dan perlindungan perempuan.

3. Melakukan pemetaan dan analisis terhadap indikator-indikator kesetaraan dan keadilan gender yang tersedia di Indonesia maupun dipakai di tingkat internasional, termasuk yang terkait dengan diskriminasi dan perlindungan perempuan.

4. Melakukan analisis kesenjangan antara payung hukum dan kebijakan 
pemerintah yang terkait dengan kesetaraan dan keadilan gender, termasuk yang terkait dengan diskriminasi dan perlindungan perempuan.

5. Membentuk kerangka konsep Indikator Komposit (Indeks) Kesetaraan dan Keadilan Gender berdasarkan data survai nasional yang terjamin keberlangsungannya, serta cakupannya yang luas.

6. Menghitung dan menganalisis Indeks Kesetaraan dan Keadilan Gender berdasarkan aspek: a) kualitas hidup, b) diskriminasi, dan c) perlindungan terhadap tindak kekerasan berbasis gender.

7. Mengidentifikasi indikator/data terkait kesetaraan dan keadilan gender, khususnya terkait dengan diskriminasi dan perlindungan perempuan yang diperlukan namun belum tersedia, sebagai dasar untuk menyusun Indeks Kesetaraan dan Keadilan Gender yang lebih akurat, sehingga dapat menjadi alat ukur, monitoring dan evaluasi kebijakan pemerintah di masa mendatang.

8. Penyajian hasil penghitungan Indeks Kesetaraan dan Keadilan Gender tahun 2007 dan 2010.

Sedangkan tujuan khusus dari penyusunan IKPUG adalah: 1) Mengidentifikasi indikator-indikator kelembagaan pengarusutamaan gender yang tersedia pada berbagai laporan dari Kementerian, Kepolisian, Lembaga Swadaya Masyarakat dan lembaga lainnya; 2) Melakukan pemetaan dan analisis terhadap indikator-indikator kelembagaan pengarusutamaan gender; 3) Membentuk kerangka konsep Indikator Kelembagaan Pengarusutamaan Gender; dan 4) Penyajian rancangan Indikator Kelembagaan Pengarusutamaan Gender.

Ada tiga dasar penyusunan IKKG: 1) IKKG dipersiapkan secara khusus untuk mengevaluasi kebijakan pembangunan lintasbidang dan antarprovinsi di Indonesia; 2) IKKG mengukur pencapaian kesetaraan dan keadilan dalam variabel-variabel output atau outcome (bukan input), sehingga dalam penggunaannya perlu dilengkapi dengan IKPUG yang mengukur variabel input; dan 3) IKKC dibangun sebagai perluasan dari Indeks Ketidaksetaraan Gender/ Gender Inequality Index (UNDP 2010). Penyusunan IKKC ini dirumuskan berdasarkan arah, strategi, dan sasaran kebijakan Pengarusutamaan Gender (PUG) dalam RPJMN 2010-2014.

Gambar 2. Konsep Pengembangan IKKG \& IKPUC

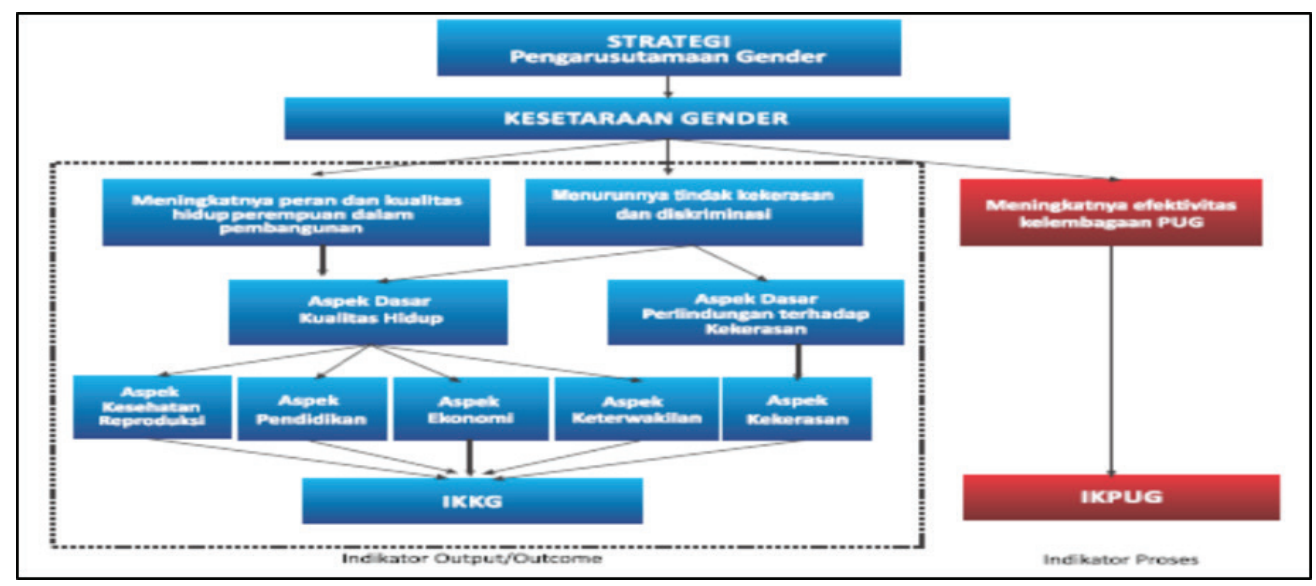

Sumber: IKKG dan IKPUG: Kajian Awal, 2012 
IKKG ini kemudian diturunkan menjadi lima komponen dan 12 indikator, yang merupakan pengembangan dari IKG/ GII dan PUG dalam RPJMN 2010-2014 sebagai berikut.

Gambar 3. Indikator-indikator dalam IKG/GII (5 Indikator) dan IKKG (12 Indikator)

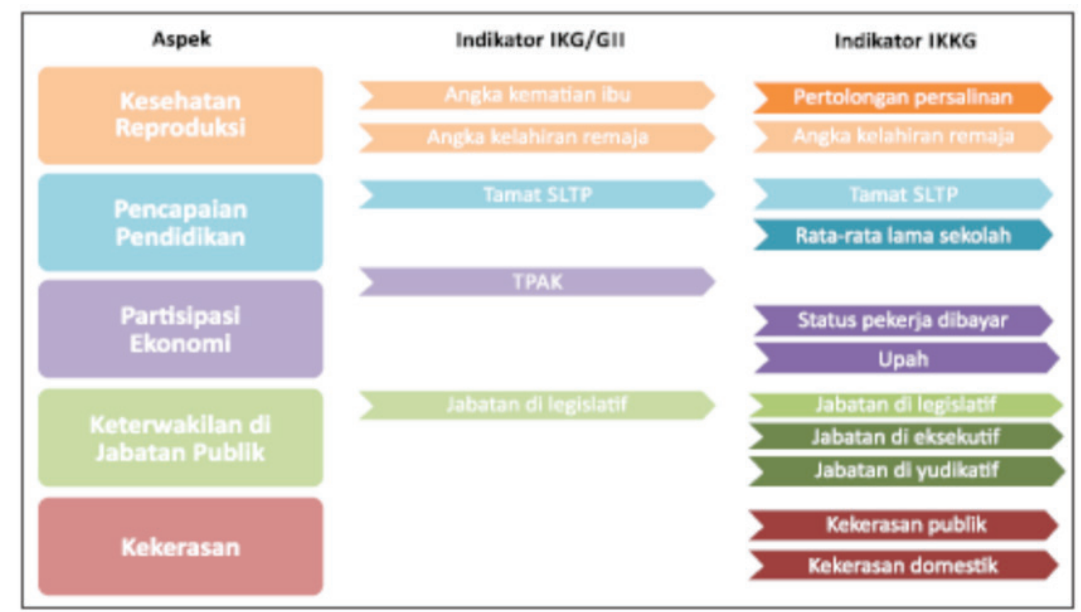

Sumber: IKKG dan IKPUG: Kajian Awal, 2012

Adapun konsep pengembangan IKPUG adalah berdasarkan aspek peningkatan efektivitas kelembagaan PUG dalam RPJMN 2010-2014. Selengkapnya adalah sebagaimana tercantum dalam gambar di bawah ini.

Gambar 4. Konsep Pengembangan IKPUG

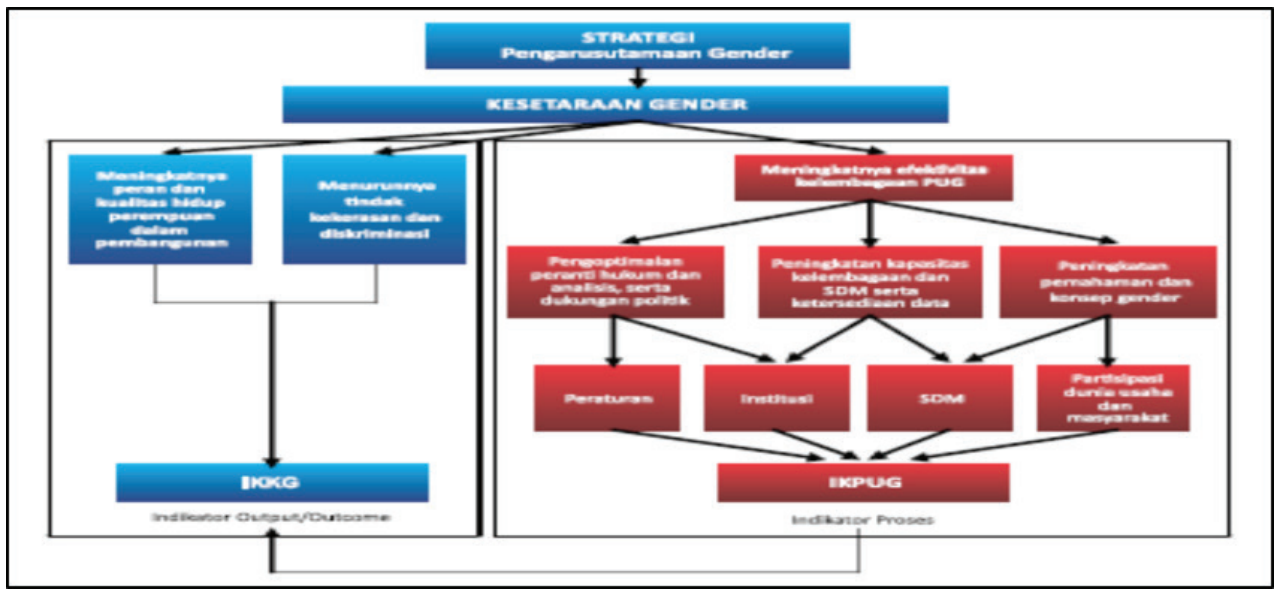

Sumber: IKKG dan IKPUG: Kajian Awal, 2012

Dari konsep ini, maka IKPUG diturunkan menjadi empat komponen dan 14 indikator sebagai berikut: 
Gambar 5. Empat Komponen dan 14 Indikator dalam IKPUG

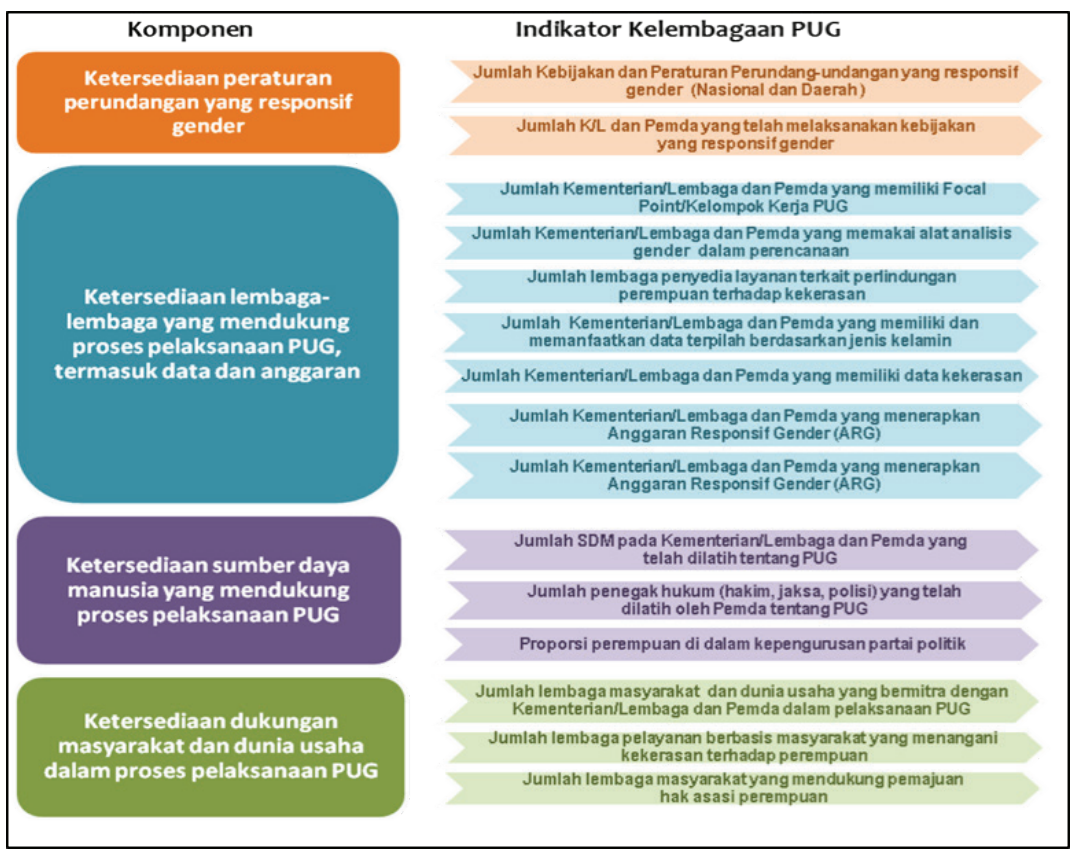

Sumber: IKKG dan IKPUG: Kajian Awal, 2012

Kajian awal tersebut dilanjutkan dengan Kajian Pendalaman Penyusunan Indeks Keadilan dan Kesetaraan Gender (IKKG) dan Indikator Kelembagaan Pengarusutamaan Gender (IKPUG) pada tahun 2015 (Bappenas-Direktorat Keluarga 2015). Berdasarkan kajian pendalaman tersebut, maka IKKG disempurnakan menjadi di bawah ini.

Gambar 6. Bagan Pemilahan dan Pemilihan Indikator untuk IKKG

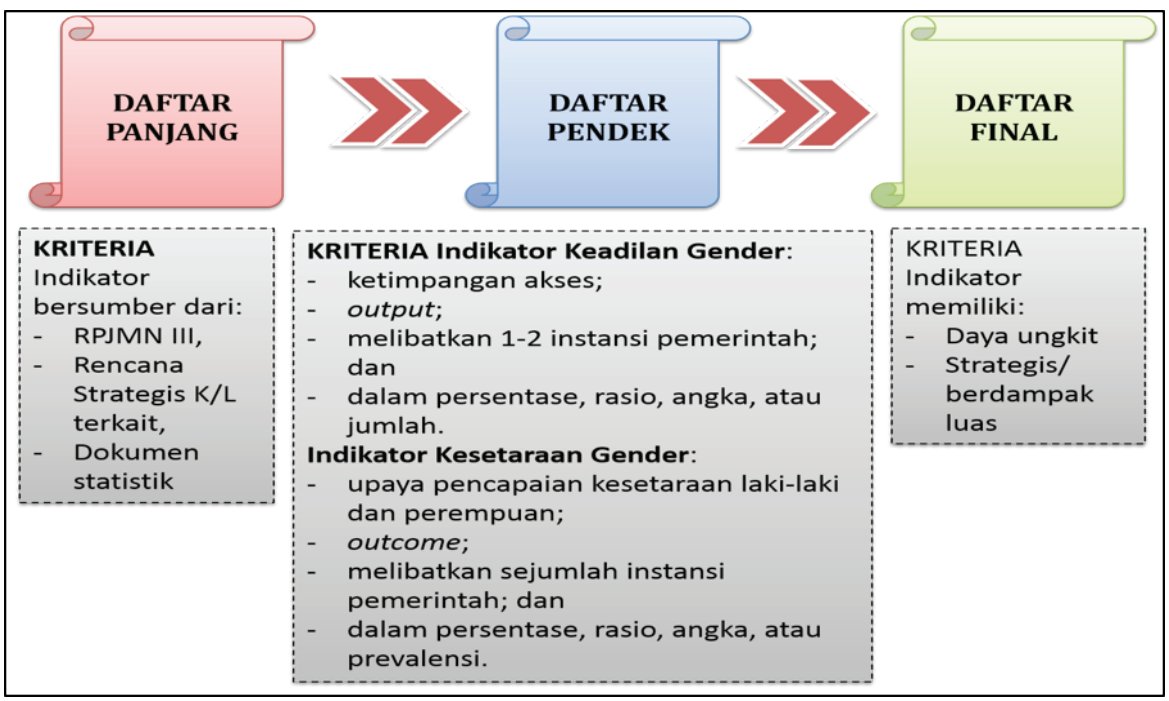

Sumber: Kajian Pendalaman IKKG dan IKPUG, Bappenas, 2015 
Dari hasil pemilahan dan pemilihan tersebut, maka ditetapkan IKKG tetap meliputi 5 aspek, yaitu aspek kesehatan reproduksi, pendidikan, pengambilan keputusan, ekonomi, dan kekerasan terhadap perempuan. Perbedaannya dengan IKKG 2012, pada kajian pendalaman ini diputuskan bahwa Indeks Keadilan Gender dihitung secara terpisah dengan Indeks Kesetaraan Gender (tidak digabungkan seperti pada perhitungan IKKG 2012). Penggabungan IKKG 2012 ini dilakukan mengingat bahwa pencapaian keadilan gender pada akhirnya adalah juga upaya menuju kesetaraan gender. Sementara pada kajian pendalaman ini, indeks pembangunan manusia untuk capaian keadilan gender dipisahkan dari indeks pembangunan manusia untuk capaian kesetaraan gender, dengan indikator untuk setiap indeks yang berbeda pula, karena: 1) Perbedaan tingkatan antara indikator keadilan gender dengan indikator kesetaraan gender; 2) Penggabungan indikator yang berbeda tingkatan dapat mengaburkan kesenjangan gender yang terjadi, dan memperumit penafsiran nilai indeks; 3) Pemisahan diperlukan untuk mendapatkan pengukuran yang jelas dan lebih akurat atas capaian keadilan gender dan capaian kesetaraan gender; dan 4) Mempermudah penanganan permasalahan terkait keadilan gender dan kesetaraan gender ke depannya. Persandingan indikator selengkapnya dari setiap aspek tersebut adalah sebagaimana tercantum pada tabel berikut.

Tabel 1. Persandingan Indikator RPJMN III, IKKG 2012, dan 2015

\begin{tabular}{|c|c|c|c|c|}
\hline ASPEK & $\begin{array}{c}\text { INDIKATOR } \\
\text { RPJMN 2015-2019 }\end{array}$ & $\begin{array}{l}\text { INDIKATOR } \\
\text { IKKG } 2012\end{array}$ & $\begin{array}{l}\text { INDIKATOR KEADILAN } \\
\text { GENDER } 2015\end{array}$ & $\begin{array}{c}\text { INDIKATOR } \\
\text { KESETARAAN } \\
\text { GENDER } 2015\end{array}$ \\
\hline $\begin{array}{l}\text { Kesehatan } \\
\text { Reproduksi }\end{array}$ & $\begin{array}{l}\text { 1. } \begin{array}{l}\text { Persentase } \\
\text { persalinan di } \\
\text { fasilitas } \\
\text { pelayanan } \\
\text { kesehatan }\end{array} \\
\text { 2. } \begin{array}{l}\text { Persentase ibu } \\
\text { hamil kurang } \\
\text { energi kronik }\end{array} \\
\text { 3. Persentase } \\
\text { kunjungan } \\
\text { neonatal } \\
\text { pertama (KN1) } \\
\text { 4. Persentase ibu } \\
\text { hamil yang } \\
\text { mendapatkan } \\
\text { pelayanan } \\
\text { antenatal ke } \\
\text { empat (K4) }\end{array}$ & 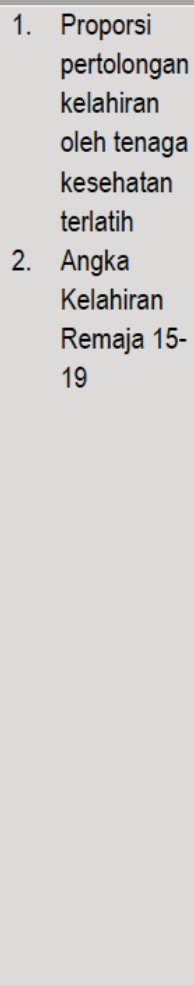 & $\begin{array}{l}\text { 1. Persentase ibu hamil } \\
\text { yang mendapatkan } \\
\text { pelayanan antenatal } \\
\text { minimal } 4 \text { kali (K4) } \\
\text { 2. Persentase persalinan } \\
\text { dengan pertolongan } \\
\text { tenaga kesehatan } \\
\text { 3. Proporsi berat bayi } \\
\text { lahir rendah laki-laki } \\
\text { dan perempuan } \\
\text { 4. Persentase anak usia } \\
\text { 0-11 bulan yang } \\
\text { mendapat imunisasi } \\
\text { dasar lengkap } \\
\text { 5. Proporsi bayi gizi } \\
\text { buruk laki-laki dan } \\
\text { perempuan } \\
\text { 6. Persentase remaja } \\
\text { laki-laki dan } \\
\text { perempuan yang } \\
\text { mengetahui tentang } \\
\text { kesehatan reproduksi } \\
\text { Jumlah peserta KB } \\
\text { aktif laki-laki dan } \\
\text { perempuan. }\end{array}$ & 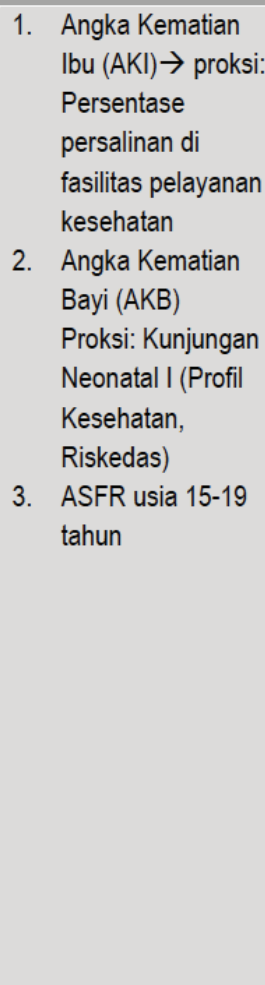 \\
\hline
\end{tabular}




\begin{tabular}{|c|c|c|c|c|}
\hline ASPEK & $\begin{array}{c}\text { INDIKATOR } \\
\text { RPJMN 2015-2019 }\end{array}$ & $\begin{array}{l}\text { INDIKATOR } \\
\text { IKKG } 2012\end{array}$ & $\begin{array}{l}\text { INDIKATOR KEADILAN } \\
\text { GENDER } 2015\end{array}$ & $\begin{array}{l}\text { INDIKATOR } \\
\text { KESETARAAN } \\
\text { GENDER } 2015\end{array}$ \\
\hline Pendidikan & 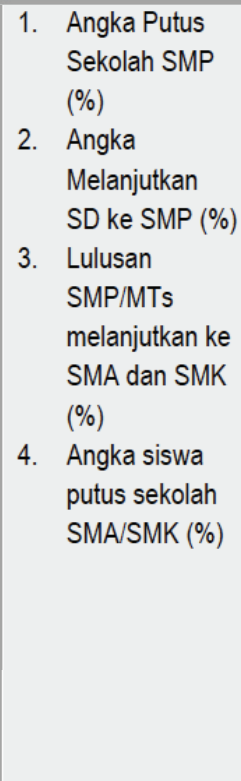 & $\begin{array}{l}\text { 1. Penduduk } \\
\text { perempuan } \\
\text { dan laki-laki } \\
\text { minimal } \\
\text { tamat } \\
\text { pendidikan } \\
\text { SLTP } \\
\text { 2. Rata-rata } \\
\text { lama } \\
\text { bersekolah }\end{array}$ & $\begin{array}{l}\text { 1. Angka partisipasi } \\
\text { sekolah laki-laki dan } \\
\text { perempuan kelompok } \\
\text { usia } 7-12 \text { tahun, usia } \\
\text { 13-15 tahun, dan usia } \\
\text { 16-18 tahun } \\
\text { 2. Angka melanjutkan ke } \\
\text { SMP } \\
\text { 3. Angka melanjutkan ke } \\
\text { SLTA (SMA, SMK) } \\
\text { 4. Angka putus SD laki- } \\
\text { laki dan perempuan } \\
\text { 5. Angka putus SMP laki- } \\
\text { laki dan perempuan } \\
\text { 6. Angka mengulang SD } \\
\text { laki-laki dan } \\
\text { perempuan } \\
\text { 7. Angka mengulang } \\
\text { SMP laki-laki dan } \\
\text { perempuan }\end{array}$ & $\begin{array}{l}\text { 1. Angka rata-rata } \\
\text { lama sekolah } \\
\text { 2. Angka harapan } \\
\text { lama sekolah laki- } \\
\text { laki dan } \\
\text { perempuan* }\end{array}$ \\
\hline $\begin{array}{l}\text { Pengambilan } \\
\text { Keputusan }\end{array}$ & $\begin{array}{l}\text { 1. Jumlah ormas } \\
\text { yang bermitra } \\
\text { untuk } \\
\text { peningkatan } \\
\text { kapasitas } \\
\text { kelompok } \\
\text { perempuan, } \\
\text { penyandang } \\
\text { difabel dan } \\
\text { kelompok } \\
\text { rentan melalui } \\
\text { kemitraan } \\
\text { dengan ormas } \\
\text { marjinal lain } \\
\text { 2. Jumlah daerah } \\
\text { yang } \\
\text { terfasilitasi } \\
\text { pendidikan } \\
\text { politik untuk } \\
\text { politisi } \\
\text { perempuan }\end{array}$ & $\begin{array}{l}\text { 1. Keterwakila } \\
\mathrm{n} \\
\text { perempuan } \\
\text { dan laki-laki } \\
\text { di parlemen }\end{array}$ & $\begin{array}{l}\text { 1. Persentase calon } \\
\text { legislatif laki-laki dan } \\
\text { calon legislatif } \\
\text { perempuan untuk: } \\
\text { - DPR } \\
\text { - DPRD Provinsi } \\
\text { - DPRD Kab/Kota } \\
\text { - DPD } \\
\text { 2. Persentase kader laki- } \\
\text { laki dan kader } \\
\text { perempuan pada } \\
\text { partai politik peserta } \\
\text { pemilu } \\
\text { 3. Persentase hakim laki- } \\
\text { laki dan perempuan di } \\
\text { pengadilan tinggi dan } \\
\text { pengadilan negeri } \\
\text { 4. Persentase jaksa laki- } \\
\text { laki dan perempuan } \\
\text { per provinsi } \\
\text { 5. Persentase Calon } \\
\text { Kepala Daerah laki- } \\
\text { laki dan perempuan di } \\
\text { tingkat Provinsi dan } \\
\text { Kab/Kota } \\
\text { 6. Persentase PNS laki- } \\
\text { laki dan perempuan di } \\
\text { tingkat K/L }\end{array}$ & $\begin{array}{l}\text { 1. Persentase } \\
\text { anggota legislatif } \\
\text { laki-laki dan } \\
\text { anggota legislatif } \\
\text { perempuan di: } \\
\text { - DPR, } \\
\text { - DPRD Provinsi dan } \\
\text { - DPRD Kab/Kota } \\
\text { - DPD } \\
\text { 2. Persentase laki- } \\
\text { laki dan } \\
\text { perempuan dalam } \\
\text { kepengurusan } \\
\text { harian partai politik } \\
\text { tingkat pusat } \\
\text { 3. Persentase laki- } \\
\text { laki dan } \\
\text { perempuan dalam } \\
\text { kepengurusan } \\
\text { tingkat daerah } \\
\text { (provinsi) } \\
\text { 4. Persentase hakim } \\
\text { laki-laki dan } \\
\text { perempuan di MK, } \\
\text { dan MA (Ketua } \\
\text { Mahkamah Agung } \\
\text { (MA) dan Wakil } \\
\text { Ketua MA, Ketua } \\
\text { Muda, Hakim }\end{array}$ \\
\hline
\end{tabular}




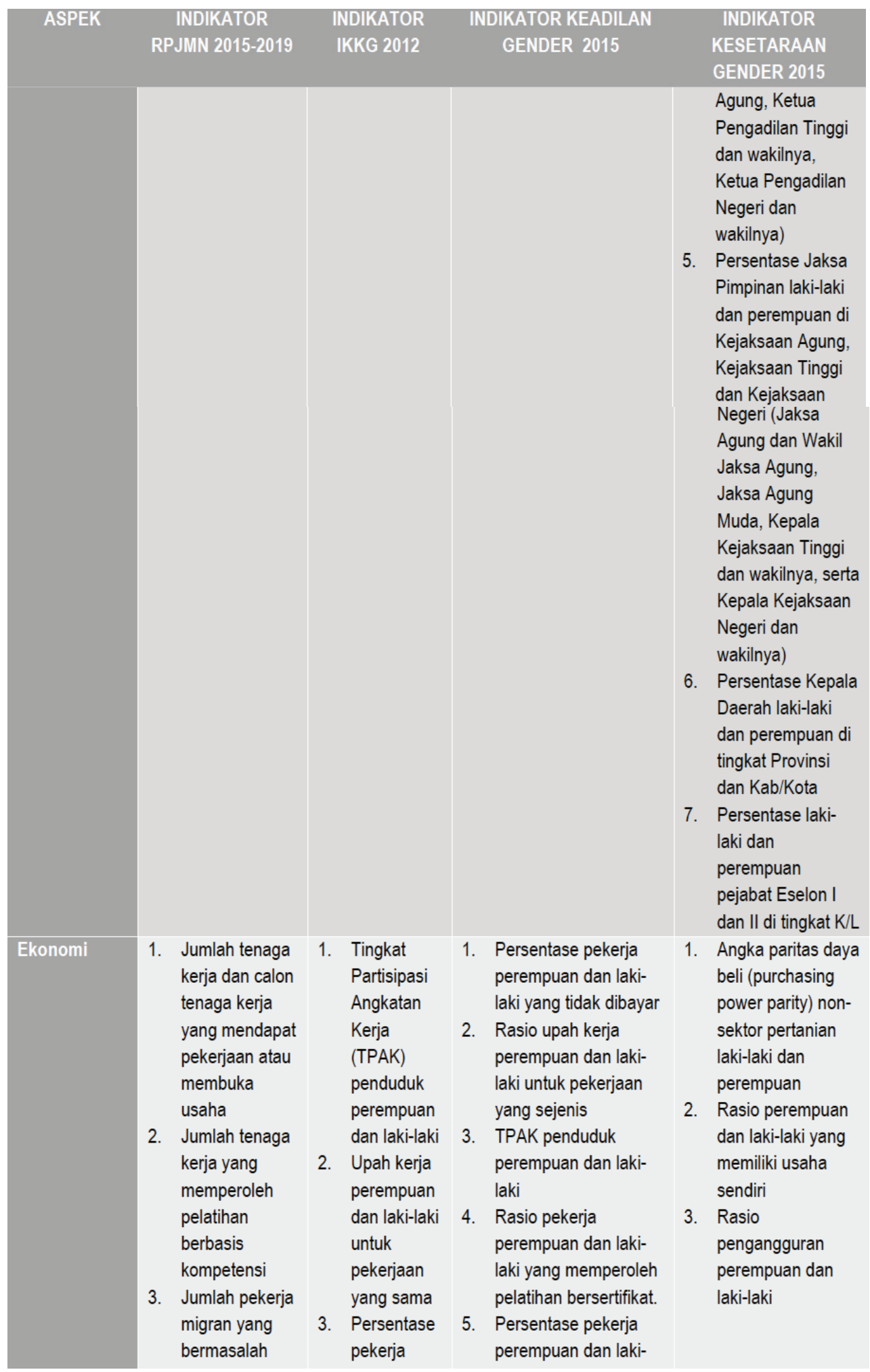




\begin{tabular}{|c|c|c|c|c|}
\hline \multirow[t]{2}{*}{ ASPEK } & $\begin{array}{c}\text { INDIKATOR } \\
\text { RPJMN 2015-2019 }\end{array}$ & $\begin{array}{l}\text { INDIKATOR } \\
\text { IKKG } 2012\end{array}$ & $\begin{array}{l}\text { INDIKATOR KEADILAN } \\
\text { GENDER } 2015\end{array}$ & $\begin{array}{l}\text { INDIKATOR } \\
\text { KESETARAAN } \\
\text { GENDER } 2015\end{array}$ \\
\hline & & $\begin{array}{l}\text { perempuan } \\
\text { dan laki-laki } \\
\text { yang } \\
\text { dibayar }\end{array}$ & $\begin{array}{l}\text { laki yang memiliki } \\
\text { kontrak kerja. }\end{array}$ & \\
\hline $\begin{array}{l}\text { Kekerasan } \\
\text { terhadap } \\
\text { Perempuan }\end{array}$ & $\begin{array}{l}\text { 1. Persentase } \\
\text { kasus } \\
\text { kekerasan } \\
\text { terhadap } \\
\text { perempuan } \\
\text { yang mendapat } \\
\text { layanan } \\
\text { komprehensif }\end{array}$ & 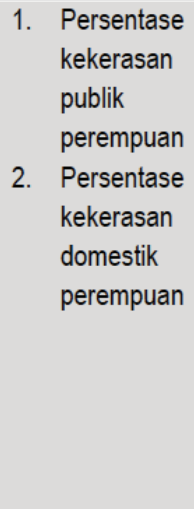 & $\begin{array}{l}\text { 1. Jumlah kasus yang } \\
\text { tercatat dan terlayani: } \\
\text { - } \text { Komnas } \\
\\
\text { - } \text { Perempuan } \\
\text { - Kepolisian } \\
\text { - } \text { KemPA } \\
\\
\text { dan Kab/Kota } \\
\text { P2TP2A } \\
\text { - Women Crisis } \\
\text { Center } \\
\text { - Kemenkes } \\
-\quad \text { Kemensos }\end{array}$ & $\begin{array}{l}\text { 1. Prevalensi } \\
\text { kekerasan } \\
\text { terhadap } \\
\text { perempuan di area } \\
\text { publik } \\
\text { 2. Prevalensi } \\
\text { kekerasan } \\
\text { terhadap } \\
\text { perempuan di area } \\
\text { domestik }\end{array}$ \\
\hline
\end{tabular}

Sumber: Kajian Pendalaman IKKG dan IKPUG, Bappenas, 2015

Sedangkan untuk IKPUG hasil kajian pendalaman 2015, dilakukan penyempurnaan indikator dengan mengacu kepada tujuh prasyarat PUG. Indikator selengkapnya hasil kajian tahun 2015 untuk IKPUG adalah sebagaimana tercantum dalam Tabel 2.

Tabel 2. Persandingan IKPUG 2012 dan 2015

\begin{tabular}{|c|c|c|}
\hline $\begin{array}{c}\text { KOMPONEN } \\
\text { KELEMBAGAAN } \\
\text { PUG }\end{array}$ & $\begin{array}{l}\text { INDIKATOR KELEMBAGAAN PUG KAJIAN } \\
\text { AWAL } 2012\end{array}$ & $\begin{array}{l}\text { INDIKATOR KELEMBAGAAN PUG } \\
2015\end{array}$ \\
\hline $\begin{array}{l}\text { Kebijakan dan } \\
\text { Peraturan } \\
\text { Perundang- } \\
\text { undangan }\end{array}$ & $\begin{array}{l}\text { 1. Jumlah Kebijakan dan Peraturan Perundang- } \\
\text { undangan Nasional dan Daerah yang } \\
\text { responsif gender (UU, PP, Perpres, Permen, } \\
\text { Perda, Pergub) } \\
\text { 2. Jumlah K/L dan Pemda yang telah } \\
\text { melaksanakan kebijakan yang responsif } \\
\text { gender (khusus Pemda: berapa jumlah } \\
\text { SKPD yang terlibat) }\end{array}$ & $\begin{array}{l}\text { 1. Jumlah K/L yang mempunyai } 7 \\
\text { prasyarat PUG } \\
\text { 2. Jumlah provinsi yang memiliki } 7 \\
\text { prasyarat PUG } \\
\text { 3. Persentase } K / L \text { yang telah membuat } \\
\text { komitmen PUG dalam kerangka legal } \\
\text { 4. Persentase program } K / L \text { yang } \\
\text { direncanakan dan dianggarkan }\end{array}$ \\
\hline Institusi & $\begin{array}{l}\text { 1. Jumlah K/L dan Pemda yang memiliki Focal } \\
\text { Point/Kelompok Kerja PUG (khusus Pemda: } \\
\text { berapa jumlah SKPD yang terlibat) } \\
\text { 2. Jumlah K/L dan pemda yang memakai alat } \\
\text { analisis gender dalam perencanaan (khusus } \\
\text { Pemda: berapa jumlah SKPD yang terlibat) } \\
\text { 3. Jumlah Lembaga penyedia layanan (P2TP2A } \\
\text { dan Unit PPA) terkait perlindungan } \\
\text { perempuan terhadap kekerasan } \\
\text { Data: } \\
\text { 4. Jumlah K/L dan Pemda yang memiliki dan } \\
\text { memanfaatkan data terpilah berdasarkan }\end{array}$ & $\begin{array}{l}\text { dengan perspektif gender } \\
\text { 5. Persentase } \mathrm{K} / \mathrm{L} \text { yang memiliki } \\
\text { kegiatan peningkatan kapasitas } \\
\text { gender secara reguler } \\
\text { 6. Rasio Polda dan unit penyedia } \\
\text { layanan terkait perlindungan } \\
\text { perempuan terhadap kekerasan } \\
\text { (UPPA) } \\
\text { 7. Persentase K/L yang bermitra } \\
\text { dengan lembaga masyarakat dan } \\
\text { dunia usaha dalam pelaksanaan }\end{array}$ \\
\hline
\end{tabular}




\begin{tabular}{|c|c|c|}
\hline $\begin{array}{c}\text { KOMPONEN } \\
\text { KELEMBAGAAN } \\
\text { PUG }\end{array}$ & $\begin{array}{l}\text { INDIKATOR KELEMBAGAAN PUG KAJIAN } \\
\text { AWAL } 2012\end{array}$ & $\begin{array}{l}\text { INDIKATOR KELEMBAGAAN PUG } \\
2015\end{array}$ \\
\hline & $\begin{array}{l}\text { jenis kelamin. (khusus Pemda: berapa jumlah } \\
\text { SKPD yang memiliki data terpilah) } \\
\text { 5. Jumlah K/L dan Pemda yang memiliki data } \\
\text { kekerasan (khusus Pemda: berapa jumlah } \\
\text { SKPD yang memiliki data tersebut) } \\
\text { Anggaran: } \\
6 . \text { Jumlah K/L dan pemda yang menerapkan } \\
\text { Anggaran Responsif Gender (ARG) (khusus } \\
\text { Pemda: berapa jumlah SKPD yang terlibat) }\end{array}$ & $\begin{array}{l}\text { PUG dan/atau perlindungan } \\
\text { perempuan. } \\
\text { 8. Persentase Pemda Provinsi yang } \\
\text { bermitra dengan lembaga } \\
\text { masyarakat dan dunia usaha dalam } \\
\text { pelaksanaan PUG dan/atau } \\
\text { perlindungan perempuan. }\end{array}$ \\
\hline $\begin{array}{l}\text { Sumber Daya } \\
\text { Manusia }\end{array}$ & $\begin{array}{l}\text { 1. Jumlah SDM pada K/L dan Pemda yang } \\
\text { telah dilatih tentang PUG. (khusus Pemda: } \\
\text { rasio SDM per SKPD per tahun) } \\
\text { 2. Jumlah penegak hukum (hakim, jaksa, polisi) } \\
\text { yang telah dilatih oleh Pemda tentang PUG. } \\
\text { 3. Proporsi perempuan di dalam kepengurusan } \\
\text { partai politik. }\end{array}$ & \\
\hline $\begin{array}{l}\text { Partisipasi Dunia } \\
\text { Usaha dan } \\
\text { Masyarakat }\end{array}$ & $\begin{array}{l}\text { 1. Jumlah lembaga masyarakat dan dunia } \\
\text { usaha yang bermitra dengan } K / L \text { dan Pemda } \\
\text { dalam pelaksanaan PUG } \\
\text { 2. Jumlah lembaga pelayanan berbasis } \\
\text { masyarakat yang menangani kekerasan } \\
\text { terhadap perempuan. } \\
\text { 3. Jumlah lembaga masyarakat yang } \\
\text { mendukung pemajuan hak asasi perempuan. }\end{array}$ & \\
\hline
\end{tabular}

Sumber: Kajian Pendalaman IKKG dan IKPUG, Bappenas, 2015

Untuk perhitungan IKPUC 2015, data yang digunakan adalah data sekunder dari Kementerian PP dan PA, yaitu hasil evaluasi pelaksanaan pembangunan pemberdayaan perempuan dan perlindungan anak tahun 2014.

\subsection{Strategi Nasional Percepatan Pengarusutamaan Gender melalui Perencanaan dan Penganggaran yang Responsif Gender (Stranas PPRG)}

Pada tanggal 1 November 2012, Surat Edaran tentang Strategi Nasional Percepatan Pengarusutamaan Gender melalui Perencanaan dan Penganggaran yang Responsif Gender (Stranas PPRG), yang merupakan inisiatif Bappenas (dan juga selalu koordinator penyusunannya), telah ditandatangani oleh empat Menteri Tim Penggerak PPRG. Keempat menteri dan SE tersebut adalah: Menteri PPN/ Kepala Bappenas (Nomor: 270/M.PPN/11/2012); Menkeu (Nomor: SE-33/MK.02/2012); Mendagri (Nomor: 050/4379A/SJ); dan Meneg PP\&PA (Nomor: SE 46/MPP$\mathrm{PA} / 11 / 2012)$.

SE Stranas PPRG memiliki 3 lampiran, yaitu: 1) Kerangka Stranas PPRG; 2) Petunjuk Teknis (Juknis) Stranas PPRG bagi K/L; dan 3) Juknis Stranas PPRG bagi Pemerintah Daerah (penyusunan Juknis tersebut dilakukan oleh 4 Tim Penggerak, dengan dikoordinasikan oleh KPP\&PA), (Bappenas, Kemenkeu, et al. 2012). Stranas PPRG ini kemudian diluncurkan di Bappenas pada tanggal 5 Maret 2013, oleh Ibu Menteri PPN/Kepala Bappenas dan 3 Tim Penggerak lainnya, dengan dihadiri oleh $34 \mathrm{~K} / \mathrm{L}$, Pemerintah Daerah Tingkat Provinsi, mitra pembangunan, LSM, dan media. PUG serta percepatannya melalui PPRG ini mendorong dilakukannya 
pendataan dan pemanfaatan data terpilah berdasarkan jenis kelamin dalam pembangunan, sehingga kebijakan yang dilakukan menjadi tepat sasaran, efektif, dan efisien. Hal ini mutlak diperlukan dalam pelaksanaan perencanaan berbasis kinerja (Performance Based Budgeting), dalam rangka reformasi birokrasi di NKRI yang dicanangkan sejak 2010, dan juga untuk mendukung tercapainya Tujuan Pembangunan Millennium (MDGs).

Stranas PPRG tersebut menjadi dasar dan mendorong penerapan PPRG di tingkat nasional dan daerah. Hal ini ditunjukkan dengan kemajuan PPRG tersebut pada tahun 2014, yang telah diterapkan di 36 kementerian/lembaga dan 34 provinsi, serta beberapa kabupaten/ kota yang telah menerapkannya dengan inisiatif dari pemerintah daerah yang bersangkutan.

\section{Pembelajaran}

Dari uraian di atas dapat ditarik beberapa pembelajaran dari penerapan PPRG di Indonesia, yaitu pertama, kemajuan penerapan PPRG hingga saat ini didukung oleh diterapkannya PUG dan PPRG dengan cara mengintegrasikannya ke dalam sistem yang sudah ada, dan tidak membuat sistem baru (yang khusus mengakomodasikan perspektif gender dalam siklus perencanaan dan penganggaran) secara terpisah. Hal ini meminimalkan resistensi dari tim penggerak dan K/L/SKPD terkait dalam menerapkan PPRC tersebut, yang kerap terjadi ketika menghadapi sesuatu yang baru. Di samping itu, dipersiapkannya mekanisme PPRC beserta juknis dan formulir/dokumen pendukung, beserta indikatornya mulai dari tahapan perencanaan dan penganggaran, koordinasi pelaksanaan, pemantauan, hingga evaluasinya-pada tahap awal penerapan PPRG, telah memudahkan para K/L/SKPD dalam menerapkannya.

Kedua, dilakukannya PPRC oleh para tim penggerak PPRG (Kementerian Perencanaan Pembangunan Nasional/ Bappenas, Kementerian Keuangan, Kementerian Dalam Negeri, dan Kementerian Pemberdayaan Perempuan dan Perlindungan Anak di tingkat nasional; serta turunannya sebagai Tim Penggerak PPRG di daerah) sesuai dengan tugas dan fungsinya selama ini. Hal ini dilakukan dengan mengintegrasikan perspektif gender dalam prosesnya, sehingga tidak menambah tugas baru bagi instansi yang bersangkutan. Mengintegrasikan perspektif gender di sini adalah menempatkan kesetaraan gender sebagai salah satu sudut pandang dalam proses perencanaan dan penganggaran program dan kegiatan, mulai dari tahap perencanaan, sampai dengan evaluasinya.

Ketiga, dilaksanakannya sosialisasi dan advokasi PPRG kepada seluruh pejabat dan staf terkait, terutama di K/L/SKPD penggerak PPRG, sehingga terwujud pemahaman yang sama dalam pelaksanaannya, termasuk upaya untuk mengintegrasikannya secara tersistem dan terlembaga. Ini mengingat bahwa mutasi/ rotasi PNS sangat sering dilakukan, dan jika staf yang mengampu PPRC ini adalah staf yang sama sekali belum mendapatkan pemahaman tentang PPRG, maka dapat berdampak kepada mundurnya pelaksanaan PPRG di instansi tersebut. Oleh sebab itu, diperlukan integrasi materi terkait PUG dan PPRG ke dalam pendidikan berjenjang kepada PNS struktural dan fungsional dari tingkat tertinggi hingga terendah, sehingga siapapun yang akan menempati posisi tersebut, sudah memiliki pemahaman yang sama. Inilah yang mendasari diintegrasikannya pelembagaan materi PUG ke dalam diklat penjenjangan PNS (baik struktural, maupun fungsional) oleh LAN dan K/L/SKPD terkait, sebagaimana yang tercantum dalam Stranas PPRG.

Keempat, dilakukannya koordinasi, pemantauan, dan evaluasi pelaksanaan yang berkala, sesuai tusi dari setiap K/L/SKPD, baik antartim penggerak, maupun antara tim penggerak dengan K/L/SKPD lainnya; sehingga penerapan PPRG ini 
dapat berjalan secara sistematis dan terlembaga. Hal ini wajib dilakukan mengingat bahwa PPRG tersebut akan diterapkan oleh seluruh K/L/SKPD sesuai dengan tusinya, dengan pemahaman yang masih sangat bervariasi.

Kelima, didorongnya data terpilah dan statistik gender untuk terlembaga dan tersistem di setiap K/ L. Data terpilah berdasarkan jenis kelamin dan statistik gender tersebut akan mendukung terwujudnya analisis dampak dari pelaksanaan pembangunan secara lebih akurat dan tepat sasaran, dan diharapkan dapat mendukung percepatan pengurangan kesenjangan pembangunan antara laki-laki dan perempuan di NKRI.

Keenam, melibatkan seluruh pemangku kepentingan dalam upaya percepatan PUG melalui PPRG tersebut. Hal ini mengingat bahwa kesenjangan gender merupakan salah satu penyebab dari kesenjangan pembangunan pada umumnya, dan penyamaan persepsi terhadap kesetaraan gender tidak dapat diselesaikan oleh salah satu K/L/SKPD saja. Oleh sebab itu, diperlukan kerjasama dengan pihak akademisi, tokoh agama/ masyarakat/ adat, organisasi massa, dan sebagainya.

Ketujuh, yang terpenting dalam penyamaan persepsi kesetaraan gender dengan pihak terkait ini adalah ditetapkannya panduan/ modul/ bahan ajar yang terstandarisasi tentang kesetaraan gender dalam perencanaan pembangunan oleh $\mathrm{K} / \mathrm{L} / \mathrm{SKPD}$ yang mengampu tugas fungsi sosialisasi materi PUG dan percepatannya melalui PPRG tersebut. Dengan demikian, maka siapapun pemberi materi tersebut, konsep yang disampaikan akan sama, sehingga tidak menimbulkan kebingungan atau bahkan resistensi/ penolakan dari peserta yang baru mendapatkan materi tersebut.

Kedelapan, mekanisme penyampaian sosialisasi/ bimbingan teknis percepatan PUC melalui PPRG ini harus tailor made, atau disesuaikan dengan K/L/SKPD dan kondisi daerah/ budaya setempat, dengan substansi yang sudah distandarisasi sebagaimana dijelaskan di atas. Jika menyampaikan sosialisasi/ bimbingan teknis di Kementerian Pertanian, maka contoh-contoh yang disampaikan juga hendaknya terkait dengan tugas dan fungsi Kementerian Pertanian, bukan K/L lainnya. Demikian pula jika kegiatan tersebut dilaksanakan bagi Pemda Provinsi Papua Barat, hendaknya isu-isu gender yang dicontohkan juga terkait dengan kondisi setempat, dan bukan menggunakan contoh-contoh isu gender yang tidak relevan dari daerah lain, misalnya di Provinsi Jawa Tengah.

Kesembilan, mengingat bahwa pemahaman PUG dan percepatannya melalui PPRG ini merupakan aspek pertama dan utama dalam pelaksanaan PPRG ini, maka sosialisasi/ advokasi/ bimbingan teknis harus dilaksanakan secara rutin di internal K/L/SKPD tersebut. Oleh sebab itu, maka Pokja PUG yang dibentuk berdasarkan Inpres No. 9 tahun 2000 tersebut hendaknya direvitalisasi dengan melibatkan unit perencana di setiap unit kerjanya. Hal ini juga untuk memastikan bahwa percepatan PUG melalui PPRG tersebut sesuai dan sejalan dengan proses dan kaidah-kaidah perencanaan dan penganggaran yang berlaku, dan bukannya berjalan sendiri di luar sistem.

Kesepuluh, koordinasi antartim penggerak harus senantiasa dijaga. Apabila terjadi perubahan terhadap kebijakan atau peraturan perundang-undangan terkait dengan perencanaan dan penganggaran tersebut, hendaknya dikomunikasikan dan didiskusikan bersama. Hal ini untuk memastikan bahwa PPRG akan selalu berada dalam koridor sistem perencanaan dan penganggaran yang berlaku, baik di tingkat nasional, maupun di tingkat daerah. 


\section{Kesimpulan dan Rekomendasi}

Berdasarkan penjelasan di atas, dapat disimpulkan bahwa percepatan PUC melalui PPRG ini dapat berkembang jauh lebih pesat dibandingkan dengan PUG itu sendiri, karena sudah diikat langsung dengan dokumen penganggaran pembangunan, tidak hanya berhenti di dokumen perencanaan saja, namun kemudian raib pada tahap penganggaran dan pelaksanaannya, sebagaimana pada periode penerapan PUC sebelumnya. Dengan demikian, maka program/ kegiatan yang telah tercantum dalam dokumen perencanaan pembangunan, harus ditindaklanjuti dengan pengalokasian anggarannya. Di samping itu, sebagai suatu siklus perencanaan, maka program/ kegiatan yang dilakukan secara responsif gender tersebut juga harus selalu dipantau dan dievaluasi pelaksanaannya, sebagai bahan perbaikan untuk perencanaan pembangunan pada periode berikutnya.

Adapun rekomendasi untuk pelaksanaan PUG dan percepatannya melalui PPRG yang paling mendesak saat ini adalah evaluasi dari program/ kegiatan yang telah dicantumkan dalam ARG selama ini:

1. Apakah program/ kegiatan tersebut mendukung pencapaian tujuan prioritas nasional dan SDGs?

2. Apakah program/kegiatan tersebut terbukti signifikan untuk mengurangi/ menghapuskan kesenjangan gender?

3. Apakah program/ kegiatan tersebut benar-benar dilakukan secara responsif gender?

4. Apakah data terpilah berdasarkan jenis kelamin dan/ atau statistik gender sudah dilembagakan sebagai dasar penerapan PPRG yang akurat dan termutakhirkan?

Hal ini untuk memastikan bahwa program/ kegiatan yang dilakukan secara responsif gender tersebut adalah program/ kegiatan teknis yang berdaya ungkit tinggi dalam mengurangi/menghapuskan kesenjangan gender. Sebagaimana yang dicantumkan di dalam Stranas PPRG, lebih baik fokus untuk melaksanakan satu program/ kegiatan yang berdaya ungkit tinggi dan signifikan dalam penghapusan kesenjangan gender, daripada melakukan banyak program/ kegiatan responsif gender yang tidak begitu signifikan hasilnya dalam pengurangan/ penghapusan kesenjangan gender, atau yang bukan bersifat program/ kegiatan teknis, atau pun pengembangan kapasitas dalam bentuk sosialisasi/ diklat PUG semata di K/L/SKPD tersebut. 


\section{Daftar Pustaka}

Bappenas. 2010. Peraturan Presiden RI No. 5/2010 tentang Rencana Pembangunan Jangka Menengah (RPJMN) 2010-2014 Buku II: Memperkuat Sinergi Antarbidang Pembangunan. Jakarta: Kementerian PPN/ Bappenas. -. 2010. PPRG. Diakses 2015. http://bappenas.go.id/index.php?cID=719.

Bappenas, Kemenkeu, Kemendagri, dan KPP\&PA. 2012. Strategi Nasional Percepatan Pengarusutamaan Gender (PUG) Melalui Perencanaan dan Penganggaran yang Responsif Gender (PPRG). Jakarta: Kementerian PPN/ Bappenas.

Bappenas-Direktorat Keluarga, Anak, Perempuan, Pemuda, dan Olahraga. 2015. Kajian Pendalaman Penyusunan Indeks Keadilan dan Kesetaraan Gender (IKKG) dan Indikator Kelembagaan Pengarusutamaan Gender (IKPUG). Jakarta.

PPN/Bappenas, Kementerian, dan KNPP. 2007. Gender Analysis Pathway (GAP): Alat Analisis Gender untuk Perencanaan Pembangunan (22 September 2007 ed.). Jakarta.

RI, Presiden. 2007. "Undang-undang Nomor 17 Tahun 2007 Tentang Rencana Pembangunan Jangka Panjang Nasional (RPJPN) 2005-2025."

Sanjoyo, Fithriyah, Aini Harisani, Yohanna M.L. Gultom, Susiati Puspasari, dan Lilis Heri Miscicih. 2012. Indeks Kesetaraan dan Keadilan Gender (IKKG) dan Indikator Kelembagaan Pengarusutamaan Gender (IKPUG): Kajian Awal. Disunting oleh Nina Sardjunani. Jakarta: Direktorat Kependudukan, Pemberdayaan Perempuan, dan Perlindungan Anak Kementerian PPN/BAPPENAS.

UN. 2001. "Gender Mainstreaming: Strategy for Promoting Gender Equality (Rev.)." Office of the Special Advisor on Gender Issues and Advancement of Women. August. Diakses 2015. www.un.org/womenwatch/osagi/pdf/factsheet1.pdf. 